AL MURABBI: Jurnal Pendidikan Agama Islam

P-ISSN (cetak) : 2477-8338

E-ISSN (online) : 2548- 1371
Program Studi Pendidikan Agama Islam https://jurnal.yudharta.ac.id/v2/index.php/pai

Volume 5 Nomor 1 Desember 2019

\title{
PANGGUNG POLITIK KYAI NU DI KABUPATEN PASURUAN ANTARA MASLAHAH UMMAT DAN SYAHWAT POLITIK
}

\author{
Miftachul Taubah, Muhammad Nur Hadi, Syaifullah \\ Fakultas Agama Islam Universitas Yudharta Pasuruan \\ mifta@yudharta.ac.id, nurhadi@yudharta.ac.id, syaifullah@yudharta.ac.id
}

\begin{abstract}
Research aims to understand the dialectic between structure and agency that puts clerics as individuals who are creative and have the capacity transformative to produce and reproduce the structure on one side of the inclined limit (limiting-disabling) and

Received: on the other hand enable (enabling) action, all done the kyai in his position as a Agustus $6^{\text {th }} 2019$ religious elite. This theme is interesting because of the many NU clerics who are directly or indirectly involved in the political map that takes place in this country.

Revised: While methodologically, this research will be designed with a qualitative approach September $5^{\text {th }} 2019$ considering the unit of study is a dynamic social phenomenon. The subjects in this Accepted: study were determined purposively. The technique used in collecting data in this study December $12^{\text {th }} 2019$ was carried out in several ways such as in-depth interviews that were not structured orlong open-ended interviens. This study also uses data sources from the analysis of written materials (literature and documents). The analysis is carried out inductively by linking data, data categorization, data comparison, mutual data relations, data reduction, and drawing conclusions. The results of this study indicate that the majority of the kyai stated that NU and politics are two entities that are not diametric, both are related to one another. NU as jam'iyah ijtima'iyyah diniyyah must be rahmatan lil alamin, as well as control for political life. NU is a social organization, not a political organization. If $N U$ bas anything to do with the government, then it is only limited to the obligation as a people.

Keywords: $\mid$ Politics, Kiai NU, Giddens Structurization
\end{abstract}

\section{PENDAHULUAN}

Penelitian ini akan membahas mengenai politik kyai NU di Kabupaten Pasuruan. Cakupan utama penelitian ini berhubungan dengan berbagai tindakan sosial yang dilakukan oleh para kyai NU dalam kedudukannya sebagai agen ${ }^{1}$ yang secara teoritis dipahami memiliki kapasitas untuk bertindak secara kreatif dalam menghadapi struktur. ${ }^{2}$

Peneliti ingin menunjukkan bahwa panggung kegiatan kyai NU dalam politik merupakan sebuah tindakan di mana cara-cara pencapaian tujuan sebuah organisasi tidak saja ditetapkan sebagai hasil atas berbagai pilihan yang telah disediakan oleh struktur NU tetapi juga yang diciptakan sendiri oleh individu yang dipahami sebagai agen yang memiliki kapasitas untuk bertindak kreatif. Dalam studi ini, penetapan cara-cara pencapaian tujuan tidak saja dipahami sebagai reaksi individu atas struktur, namun dapat juga timbul sebagai respon generatif dalam usahanya mencapai tujuan

${ }^{1}$ Horikoshi, Hiroko, 1976, " A Traditional Leader in a Time of Change: The Kyai and Ulama in West Java". Disertasi Doktor, University of Illinois, : 68.

${ }^{2}$ Ritzer, George, 2010, Sociological Theory, Singapore: McGraw-Hill Book. Companies House, Inc. : 213. 
organisasi. Penekanan pada pola tindakan kreatif individu ini didasari oleh pemikiran utama Giddens tentang teori strukturasi yang menekankan pada tindakan aktif individu untuk memproduksi, mereproduksi, dan mentransformasikan struktur yang di satu pihak bersifat membatasi (limiting) dan di pihak lain membisakan (enabling). ${ }^{3}$

Perhatian penelitian ini pada proses dialektika di antara struktur dan keagenan sebagai dua hal yang tidak dapat dipisahkan. Dengan kata lain, keduanya sangat saling berkaitan. Tindakan sosial (social action) menciptakan struktur dan hanya melalui tindakan sosial sajalah struktur diproduksi dan direproduksi yang memungkinkan struktur dapat bertahan dari satu waktu ke waktu yang lain.

Berdasarkan pada uraian teoritis di atas dalam tradisi Islam, kyai atau ulama dianggap sebagai pewaris para nabi yang memiliki tugas ganda yakni mengemban misi keagamaan dan misi sosialkemasyarakatan, lihat juga Saefudin Zuhri (1999: 201). Karena itu, ia harus ikut serta mewujudkan pengembangan masyarakat madani (civil society) seperti yang menjadi tujuan organisasi NU. ${ }^{5}$

Fenomena Laris manisnya para kyai NU dalam "pernikahan” politik pada pemilu presiden 2004 ini, menandakan bahwa budaya politik di Indonesia masih menggunakan traditional-religiopolitical-system (sistem politik tradisional berlandaskan keagamaan). NU memang memiliki modal besar, yakni keberadaan sistem teologi yang mengakar dalam tradisi. Dalam Religion and Political Development (1970), Donald E. Smith menggambarkan model politik negara berkembang yang menggunakan agama sebagai sistem politik tradisionalnya. Agama memberikan kerangka makna dan pengalaman umum bagi masyarakat, sehingga dengan sosialisasi sederhana melalui simbol agama, ritual, karisma orang suci, fatwa halal-haram, dan lain-lain pada masyarakat tradisional dapat disatukan dalam format tertentu. ${ }^{6}$ Hal tersebut terjadi karena agama dan budaya merupakan "ibu dan anak" yang saling melahirkan.

${ }^{3}$ Kata "membisakan" dipakai dalam penelitian ini untuk menggantikan kata “enabling” yang dipakai Giddens dalam teori strukturasinya. Dalam praktek penterjemahan, khususnya dalam karya Giddens, kata "enabling" sering diterjemahkan dengan kata "memungkinkan". Saya secara sengaja memilih kata "membisakan" karena akar kata "able" dalam bahasa Indonesia berarti "bisa”. Dari sanalah kata "membisakan" -walaupun mungkin kurang lazim ditemukan.

5 Tujuan Organisasi NU didirikan adalah menegakkan ajaran Islam menurut paham Ahlussunnah waljama'ah di tengah-tengah kehidupan masyarakat, di dalam wadah Negara Kesatuan Republik Indonesia. Usaha Organisasi 1. Di bidang agama, melaksanakan dakwah Islamiyah dan meningkatkan rasa persaudaraan yang berpijak pada semangat persatuan dalam perbedaan. 2. Di bidang pendidikan, menyelenggarakan pendidikan yang sesuai dengan nilai-nilai Islam, untuk membentuk muslim yang bertakwa, berbudi luhur, berpengetahuan luas. 3. Di bidang sosial budaya, mengusahakan kesejahteraan rakyat serta kebudayaan yang sesuai dengan nilai keislaman dan kemanusiaan. 4. Di bidang ekonomi, mengusahakan pemerataan kesempatan untuk menikmati hasil pembangunan, dengan mengutamakan berkembangnya ekonomi rakyat. 5. Mengembangkan usaha lain yang bermanfaat bagi masyarakat luas.

${ }^{6}$ Sah-sah saja para aktor politik itu memanfaatkan apapun demi keberhasilan agenda politiknya, termasuk politisasi agama (taudrif al-din fi al-siyasah). Dalam masyarakat Indonesia, di mana posisi agama masih menjadi faktor penting, memisahkan agama dari politik merupakan kemustahilan. Apalagi NU yang memiliki sistem keagamaan yang masuk dalam ranah kulturalisasi. Para politisi menggunakan apa yang disebut Ibnu Khaldun sebagai "ashabiyyah" (solidaritas kelompok) yang sudah terbalut oleh ketaqlidan religius, sebagai alat bagi mobilisasi massa warga nabdliyyin. Islamnya NU yang terkategorikan dalam agama sebagai sistem budaya, menjadikannya lekat erat dengan manipulasi politis. 


\section{Teori Strukturasi dari Giddens}

Teori strukturasi Giddens dalam dua dekade belakangan ini dipakai dalam lapangan kajian (field of studies) yang sangat luas: mulai dari kajian tentang manajemen, organisasi, birokrasi pemerintahan, hingga sistem informasi (information).( Pozzebon and Pinsonneault, 2001: 205). Pada dasarnya, argumentasi utama teori strukturasi Giddens menolak premis yang membelah secara terpisah dimensi objektif dan subjektif dari sebuah realitas. Dengan argumentasi itu, Giddens (2014) mencoba membantah premis yang dipegang teguh oleh penganut teoretisi strukturalis (yang menganggap individu sebagai produk dari struktur yang bersifat objektif) dan sekaligus premis yang diyakini tradisi fenomenologis (yang menganggap individu sebagai agen otonom yang membentuk dunia di sekitarnya) (Rose and Hackney, 2003: $1)$.

Karena itu, dalam tindakan itu semata-mata dipandang sebagai hasil dari determinisme atau ditentukan oleh struktur sebagaimana dipahami penganut paham strukturalis Parsonian (Holton, 2011), atau sebagai kontras, yang dipahami oleh penganut paham interpretatif (Sandstrom, 2001) yang menekankan penafsiran subjektif sebagai dasar dari sebuah tindakan sosial. Dengan kata lain, penelitian ini mengaplikasikan dan sekaligus mengintegrasikan perspektif makro yang menekankan pentingnya peran struktur dan perspektif mikro yang memandang individu sebagai titik tolak untuk memahami sebuah tindakan sosial (Barnes, 2001).

Teori Strukturasi mengajukan meta-teori yang bersifat integratif yang mengakui dan memasukkan kedua dimensi itu dan yang sekaligus menerima dualitas struktur dan aksi. Dengan kata lain, teori strukturasi berusaha untuk mensintesiskan kategori-kategori klasik dari struktur dan agen dalam kerangka dialektis. Sumbangan utama dari teori strukturasi ini terutama terdapat pada artikulasinya yang jelas mengenai bagaimana institusi-institusi sosial diproduksi dan direproduksi dari waktu ke waktu (Holmernadessan, 1997: 6).

Secara umum dapat dinyatakan bahwa Giddens memusatkan perhatiannya pada proses dialektika di mana praktik sosial, struktur dan kesadaran diciptakan. Sebagai refleksi aktivitas, agen dan struktur merupakan ciri tindakan pelaku sehari-hari sebagai ribadi yang melibatkan perilaku orang lain. Dalam tindakan ini, pelaku tidak hanya memonitor arus aktivitas yang mengharapkan orang lain berbuat yang sama dengan aktivitasnya sendiri, melainkan mereka juga secara rutin memonitor aspek-aspek sosial ainnya. Dalam pandangan Giddens, agen dan struktur tidak berada dalam keadaan bebas satu sama lain, sistem sosial dilihat baik sebagai media maupun sebagai hasil tindakan pelaku dan sistem sosial yang secara berulang-ulang mengorganisir kebiasaan pelaku. 
Menurut Giddens, struktur hanya ada di dalam dan melalui aktivitas pelaku manusia (Giddens; 2014: 256). Giddens tidak menyangkal fakta bahwa struktur dapat memaksa atau mengendalikan tindakan, tetapi ia merasa bahwa para sosiolog telah melebih-lebihkan peran memaksa struktur ini. Para sosiologpun telah gagal memperhatikan fakta bahwa struktur selalu membatasi maupun memungkinkan tindakan (Giddens; 2014: 63). Struktur sering memberikan kemungkinan bagi pelaku untuk melakukan sesuatu yang sebaliknya tak mampu mereka kerjakan.

Dalam konteks sosial yang luas, tindakan manusia banyak dikendalai oleh hadirnya hubungan kekuasaan. Giddens melihat semua tindakan sosial selalu melibatkan hubungan kekuasaan. Ia berpandangan bahwa kekuasaan sebagai kemampuan untuk membuat sebuah perbedaan untuk mengubah sesuatu dari keadaan sebelumnya. Kemampuan ini disebut oleh Giddens dengan istilah kapasitas transformatif (transformative capacity). Menurutnya, gagasan tentang keagenan melibatkan kapasitas untuk melakukan transformasi yang tiada lain adalah kekuasaan yang digunakan untuk mengubah sesuatu atau tindakan orang lain. Kekuasaan inilah yang kerap berfungsi sebagai kendala bagi tindakan orang-orang yang mengurangi kebebasan mereka untuk bertindak. Dengan demikian kekuasaan meningkatkan kebebasan untuk bertindak dari para agen yang memiliki. Apa yang menjadi kendala bagi seseorang memungkinkan yang lain untuk bertindak lebih.

Menurut Giddens, pada dasarnya terdapat tiga modalitas yang menghubungkan tindakan manusia dan struktur sosial. Ketiganya adalah: skema interpretatif (interpretative schemes) yang berfungsi sebagai struktur pemaknaan (structure of signification); sumber-sumber (resources) yang berfungsi sebagai struktur dominasi (structure of domination); dan, aturan-aturan (rules or norms)-yang berfungsi sebagai struktur legitimasi (structure of legitimation) (Giddens, 1984).

Menurut Giddens, manusia memiliki apa yang disebutnya dengan "reflexive monitoring of action" dalam mana manusia secara terus menerus memiliki kesanggupan untuk berpikir apa yang mereka lakukan dan mengevaluasi apakah tindakan-tindakan mereka berkesesuaian dengan tujuan yang mereka ingin capai. Dalam konteks ini, apabila manusia menganggap tujuannya tidak tercapai atau tujuannya tidak mungkin dicapai dengan cara tertentu, maka mereka dapat mulai memperkenalkan cara baru dalam bertindak yang pada gilirannya akan mendorong perubahan pada pola-pola interaksi dan pada akhirnya struktur sosial.

Untuk tujuan meringkas argumentasi utama Giddens, dapat dikatakan bahwa, konsep dasar dari agen dan keagenan melibatkan kemampuan individu untuk mentransformasikan dunia di sekitarnya melalui tindakan-tindakan sosial mereka sebagaimana juga berkemampuan untuk mereproduksikannya. Walaupun begitu, ini tidak berarti bahwa para agen dengan demikian 
telah mentransformasikan masyarakat, atau untuk hal itu mereproduksikannya dalam cara-cara yang mereka maksudkan. Menurut Giddens, tindakan manusia bisa saja menghasilkan akibatakibat yang tidak diantisipasi sebelumnya oleh para agen. Akibat-akibat yang tidak dibayangkan sebelumnya itu dapat juga menghasilkan pola-pola tindakan yang tidak selamanya dimaksudkan untuk diproduksi oleh para agen.

\section{Kritik pada Teori Strukturasi Giddens}

Walaupun pemikiran Giddens tentang teori strukturasi masih berkembang pesat hingga saat ini, pemikirannya tidak terlepas dari beberapa kritik. Salah satu kritik utama terhadap teori ini adalah relevansinya secara langsung terhadap penelitian empiris. Gregson (1989), misalnya, menganggap teori strukturasi beroperasi pada "tingkat generalisasi yang terlalu tinggi untuk dapat membantu peneliti memanfaatkannya dalam setting empiris yang khusus.

Sementara itu, Archer (1982) mengkritik pemikiran Giddens dengan mengatakan bahwa keterikatan satu sama lain di antara keagenan dan struktur dalam pemikiran Giddens terlalu ditekankan secara berlebihan. Dalam pandangan Archer, Giddens memberi tekanan terlalu besar pada kemampuan agen untuk mentransformasikan struktur dengan cara mengubah tindakan mereka-membayangkan seakan-akan struktur sosial berubah secara serta-merta hanya karena agen berubah berperilaku.

Pada bagian lain, Craib (1992: 108) menganggap teori Strukturasi tidak memberikan sesuatu yang jelas untuk diuji atau ditemukan di lapangan. Beberapa ahli lain, karena itu menganggap teori Strukturasi sebagai meta-teori sebuah cara pandang tentang dunia daripada sebagai penjelasan tentang tindakan sosial yang secara empiris dapat diuji (Weaver dan Gioia,1994)

Dalam hal ini, Giddens menolak anggapan bahwa teori Strukturasi tidak memiliki relevansi dengan penyusunan agenda penelitian sosial. Giddens mencoba menyebutkan secara jelas apa yang menurutnya secara potensial dapat menjadi kontribusi penting dari teori Strukturasi terhadap penelitian sosial. Giddens misalnya menyebut sepuluh proposisi penting teori Strukturasi untuk membantu para peneliti memperoleh orientasi yang lebih memadai tentang penggunaan teori Strukturasi dalam penelitian sosial.

Giddens sendiri sering mengatakan bahwa teori Strukturasi tidak pernah dimaksudkan sebagai sebuah program penelitian yang konkret (Giddens, 1983: 77). Bahkan, ia sebenarnya sangat kritis terhadap mereka yang mencoba mengadopsi teori Strukturasi ke dalam penelitian secara "apa adanya"; dalam ekspresinya, Giddens (1991: 213) menganjurkan agar teori Strukturasi digunakan dalam "semangat kritis dan sebagai pembanding" ("a sparing and 
critical fashion). Dalam ekspresi yang lain, Giddens menyebut teori Strukturasi lebih masuk akal apabila diperlakukan sebagai peralatan yang bermanfaat untuk meningkatkan kepekaan (sensitizing devices) atau memberikan penjelasan tentang logika penelitian terhadap aktivitas-aktivitas sosial dan produk-produk kultural (Giddens, 1991: 213).

\section{METODE}

Menyesuaikan dengan persoalan yang diajukan, penelitian ini menggunakan paradigma penelitian kualitatif (Berg, 1998: 59, Alvesson,2000:12, Denzin, 2000: 189, Maunati, 2004: 50). Dalam paradigma penelitian kualitatif ini tidak hanya berambisi mengumpulkan data dari sisi kuantitasnya, tetapi juga ingin memperoleh pemahaman yang lebih mendalam dibalik fenomena yang berhasil didokumentasikan. Pendekatan kualitatif digunakan karena tema penelitian ini menitikberatkan pada kajian konseptual yang berupa pemikiran dan bagaimana pemikiran itu tersosialisasi. Seperti disebutkan Bogdan dan Biklen (1982) diantara kunci pendekatan ini, pengungkapan makna (meaning) merupakan hal paling esensial, peneliti sebagai instrumen kunci dan adanya pendeskripsian fenomena atas objek.

Perspektif utama penelitian ini didasarkan pada argumentasi umum Giddens yang mencoba mengintegrasikan pendekatan makro-mikro, objektif-subjektif, dan kolektif-individual. Dikenal dengan nama pendekatan messo, Giddens menawarkan satu kerangka yang menjembatani pertentangan di antara pendekatan strukturalis dan fenomenologis. Dalam perspektif Giddens, tindakan dipahami sebagai hasil modifikasi yang kompleks di antara individualitas (agen) dan sosialitas (struktur) daripada semata-mata sebagai hasil determinisme struktur sebagaimana sering dipahami oleh penganut paham strukturalis Parsonian. (Holton, 2001), atau sebagai kontras, yang dipahami oleh penganut paham interpretif (Sandstrom, 2001) yang menekankan penafsiran subjektif sebagai dasar dari sebuah tindakan sosial.

Dengan demikian, mengadaptasi pendekatan Giddens, penelitian ini mengaplikasikan dan sekaligus mengintegrasikan Perspektif makro yang menekankan pentingnya peran struktur dan perspektif mikro yang memandang individu sebagai titik tolak untuk memahami sebuah tindakan sosial (Barnes, 2001). Dalam penelitian ini, teori Giddens dipakai sebagai pijakan awal (point of departure) daripada diletakkan sebagai teori yang hendak diuji. Pemikiran Giddens tentang individu sebagai agen yang secara aktif mengkonstruksi dan merekonstruksi struktur melalui tindakantindakan kritis dan kreatif merupakan bagian penting dari kajian dalam penelitian ini (Giddens, 1984: 17). Implikasi metodologis atas pendekatan Giddenians dalam penelitian ini adalah, pola-pola tindakan para agen adalah hasil modifikasi kompleks yang merupakan hasil penemuan original (original invention) yang memiliki sifat sosialitas (struktur) dan individualitas (keagenan) sekaligus. 


\section{HASIL DAN PEMBAHASAN}

\section{Paradigma Politik Kyai: Idealitas Khittah dan Syahwat Politik}

Kajian-kajian tentang kyai memperlihatkan kelebihan yang dimiliki sosok kyai. Lazimnya, kyai merupakan gelar yang disandang oleh seseorang yang mempunyai kelebihan di bidang ilmu-ilmu hukum (Fiqh, Tauhid dan Tasawwuf). dalam agama Islam. Mereka mempunyai peran yang essensial dalam masyarakat. Di samping itu keberadaan kyai dalam masyarakat mendominasi pengaruh kultural.

Setidaknya ada tiga faktor penting mengapa keberadaan kyai di masyarakat terasa penting. Pertama, tingginya derajat kyai dalam membangun jaringan dengan komunitas di luarnya, baik sesama kyai ataupun pertemuan dengan jaringan-jaringan terrtentu, sehingga memungkinkan mereka memperoleh informasi baru yang dimiliki para santri dan masyarakat sekitarnya.

Kedua, posisi sentral dan ketokohan kyai di desa dan di pesantrennya, menjadikan mereka sebagai sumber rujukan bagi orang dari luar desa, di mana orang-orang yang datang ke desa tak bisa mengabaikan eksistensi dan peran kyai. Ketiga, sebagai dampak langsung maupun tidak langsung dari posisinya, kyai biasanya memiliki kelebihan yang bersifat material dibandingkan dengan masyarakat sekitarnya, termasuk memiliki akses informasi yang lebih baik. Dalam optik akademik, istilah kyai untuk pertama kalinya diperkcnalkan Geertz pada tahun 1960 dalam kerangka studi antropologi untuk mewakili sosok ahli agama. Sedangkan Horikoshi secara konsisten membedakan penggunaan istilah kyai dari ulama karena fungsi formal yang diperankannya. Ulama lebih memerankan fungsifungsi administratif, sedangkan kyai cenderung bermain pada tataran kultural.

Menurut Miftah Faridl, fenomena perbedaan perilaku sosial politik di kalangan kyai, dalam banyak hal, dipengaruhi oleh sekurang-kurangnya dua faktor. Pertama, faktor posisi sosial kyai yang menurut studi-studi terdahulu memperlihatkan adanya suatu kekuatan penggerak perubahan masyarakat. Studi yang dilakukan Horikoshi (1978), misalnya, menunjukkan kekuatan kyai sebagai sumber perubahan sosial, bukan raja pada masyarakat pesantren tapi juga pada masyarakat di sekitarnva. Sementara Gecrtz (1960) menunjukkan kyai sebagai makelar budaya (cultural brokers) dan menyatakan bahwa pengaruh kyai terletak pada pelaksanaan fungsi makelar ini.

Meskipun secara politik kyai dikategorikan sebagai sosok yang tidak mempunyai pengalaman dan kemampuan profesional, tetapi secara sosial terbukti mampu menjembatani berbagai kepentingan melalui bahasa yang paling mungkin digunakan. Kedua, faktor kekuatan personal yang diwarnai oleh pemikiran teologis yang menjadi dasar perilaku yang diperankannya. Sebagai sosok yang diidentifikasi memiliki kekuatan kharismatik di tengah-tengah masyarakatnya, kyai dipandang memiliki kemampuan "luar biasa" untuk menggerakkan masyarakat khususnya dalam menentukan pilihan-pilihan politik. Dia bukan politisi, tapi kalkulasi politiknya yang dianggap "fatwa" politik yang 
terakhir untuk diikuti. Kasus Gus Dur yang tetap pada pendiriannya untuk mempertahankan posisinya sebagai Presiden RI. ketika itu, seperti diketahui banyak kalangan, sebetulnya karena "nasihat-nasihat" kyai yang mendorong untuk mengambil keputusan seperti itu. Hubungan kausalitas antara kedua faktor inilah yang kemudian dielaborasi secara kritis dalam penelitian ini. Penelitian perselingkuhan kyai dan kekuasaan yang dilakukan Endang Turmudi (2004) sangat aktual untuk memotret peran politik kyai di era reformasi ini. Buku yang meneropong pasang surut perpolitikan kyai ini dapat menjadi bahan rujukan untuk melihat peran kyai dalam pemilu mendatang. Kendati hanya meneliti peran kyai di Jombang, Jawa Timur, namun diyakini hasilnya adalah representasi dari peran kyai Nahdlatul Ulama di daerah-daerah lain.

Peran kyai dalam kancah politik nasional sempat menyurut sejak NU mengeluarkan kebijakan "kembali ke khittah". Namun, sebagian kalangan menyebut, penyebab kyai mundur dari ruang politik sebenarnya akibat para kyai tergusur dari PPP, saat partai itu dipimpin J. Naro. Namun, seiring reformasi yang ditandai dengan jatuhnya rezim Soeharto, peran politik kyai kembali terbuka. Ini bisa ditandai dengan munculnya PKB yang disokong penuh kyai NU. Mencoloknya perolehan suara PKB dalam Pemilu 2004 misalnya dapat juga menandai kebangkitan kyai NU. Bahkan suara PKB secara nasional 60 persennya dipasok dari Jawa Timur yang menjadi basis kaum nahdhiyin. Tapi dalam Pemilu 2009, suara PKB anjlok akibat konflik internal dan munculnya partai lain yang bebasis NU seperti PKNU.

Selain berpolitik langsung melalui partai, para kyai juga dalam mengembangkan otoritasnya banyak yang lebih memilih mengadu tawar dengan penguasa atau elite tertentu. Praksis mereka adalah menjadi pelegitimasi kekuasaan. Kyai dan penguasa berkolaborasi dan saling tawar hingga kedua pihak merasa saling diuntungkan.

Dari perspektif pemerintah, kekuasaan kyai cukup kuat untuk mempengaruhi tindakan sosial-politik masyarakat. Hal ini karena para kyai adalah pemegang legitimasi keagamaan. Legitimasi kyai ini oleh pemerintah atau para elite politik dapat digunakan untuk melegalkan tindakan-tindakan duniawi mereka (Wawancara dengan KH. Ahmad Munadi 22 Mei 2019).

Otoritas kyai tak selamanya langgeng. Tak sedikit kyai yang otoritasnya hancur akibat berselingkuh dengan penguasa atau memang mabuk kekuasaan. Pada saat umat sudah tak percaya lagi dengan otoritas kyai, saat itu juga umat secara perlahan akan meninggalkannya. Kasus ini banyak terjadi pada zaman Orde Baru. Ketika kyai berbondong-bondog masuk Golkar, umat tidak otomatis ikut, mereka bahkan malah menjauhi sang kyai.

Endang Turmudi (2004: 264) berpendapat, perselingkuhan kyai dengan penguasa tak akan menghilangkan peran dan otoritas kyai secara keseluruhan. Kyai sebagai penjaga moral dan nilai-nilai masih relevan dan berjangka panjang. Sebab pada dasarnya kyai dapat dikategorikan ke dalam tiga 
jenis, yaitu kyai pesantren, kyai tarekat, dan kyai yang terlibat dalam politik. Jenis kyai yang terakhir inilah sebenarnya yang rawan berselingkuh dengan penguasa dan mabuk kekuasaan.

Deskripsi di atas menggambarkan bahwa kyai sebenarnya tidak akan pernah terlepas dari politik. Begitu juga dengan hasil penelitian ini. NU yang menjadi sentral dari organisasi para kyai menjadi media penelitian sejauhmana kyai berpresepsi tentang keterlibatan kyai dengan politik kekuasaan.

Pandangan tentang hubungan NU dan politik sesungguhnya bagai pinang dibelah dua, keduanya tidak dapat dipisahkan. Mayoritas kyai menyatakan bahwa NU dan politik adalah dua entitas yang tidak bersifat diametral, keduanya berhubungan satu sama lain. Sebagaimana yang dikatakan oleh K.H. KH. Ali Mukhtarom, bahwa manusia tidak akan pernah lepas dari kehidupan politik karena manusia adalah makhluk politik (zoon politicon). Begitu juga NU, sebagai organisasi yang memiliki massa besar, NU tidak bisa menghindar dari kehidupan politik. Hanya saja, politik NU haruslah politik kebangsaan bukan politik praktis yang sibuk memperebutkan kekuasaan. NU sebagai jam'iyah ijtima'iyyah diniyyah harus menjadi rabmatan lil alamin, sekaligus kontrol bagi kehidupan politik (Wawancara, tanggal 24 Mei 2019).

Senada dengan K.H. Ali Mohtarom, K.H. Ahmad Junaidi Soleh, mengungkapkan jika warga NU bersikap apolitik maka Indonesia bisa hancur. Kyai Ahmad Junaidi mencontohkan pada pemilu 2009 silam, jika warga NU tidak ikut berpartisipasi maka tatanan demokrasi yang diinginkan bangsa Indonesia tidak akan terwujud. Sebagaimana yang dikatakan oleh Ali Mohtarom, Kiai Ahmad Junaidi Soleh juga menggarisbawahi bahwa yang dimaksud politik dalam konteks hubungannya dengan NU bukan politik kekuasaan melainkan politik partisipatoris, yaitu politik di mana NU juga berperan aktif dalam membangun bangsa dan negara (civil Society) (Wawancara, tanggal 24 Mei 2019).

Pendapat berbeda dengan substansi yang sama disampaikan Kyai Mujtaba Abdusshomad, walaupun NU membutuhkan pemerintah, tetapi NU tidak ada hubungannya dengan politik. NU adalah sebuah organisasi kemasyarakatan, bukan organisasi politik. Jika NU ada hubungannya dengan pemerintah maka itu hanya sebatas kewajiban sebagai rakyat. Kyai Mujtaba memahami bahwa peran politik yang dimainkan oleh NU haruslah sesuai dengan cita-cita para pendiri NU terdahulu, yakni ikut menciptakan masyarakat yang sejahtera (Wawancara, tanggal 28 Mei 2019).

Pendapat-pendapat di atas hampir sama dengan yang dipaparkan oleh semua kyai, peneliti tidak mendapatkan perbedaan pandangan dari para kyai yang menjadi informan. Peneliti mendapatkan pengembangan informasi di atas dari KH. Wildan Bin Khoiron Syakur, beliau secara gamblang memberikan argumentasi mengapa NU tidak dapat dipisahkan dengan hiruk pikuk politik, beliau mengatakan:

"Saya kira ini karena NU sendiri kan lahir pada saat situasi politik sedang panas. Ketika perang dunia I selesai tahun 1918, di dalam negeri pergerakan kemerdekaan mulai tumbuh. Dan ini 
memang sudah dimulai sejak awal abad XX yang kita sebut sebagal awal kebangkitan nasional. Tahun 1905 SDI (Serikat Dagang Islam) lahir; tahun 1908 Budi Oetomo lahir; tahun 1912 Muhammadiyah lahir, 1914 SDI yang dipelopori oleh orang-orang Belanda yang berpaham kiri juga muncul, bahkan akhirnya organisasi ini terseret ke dalam PKI pada tahun 1920. Kemudian tahun 1924 PKI memberontak. Pemberontakan yang tidak matang itu, akhirnya merugikan proses perjuangan kemerdekaan. Nah, tahun 1926 NU lahir. Antara tahun 19241926 itu, di samping orang-orang pergerakan, banyak kyai dan santri yang ditangkap Belanda dengan tuduhan komunis. Ada yang mencari-cari, apakah kelahiran NU tersebut tidak ada hubungannya dengan upaya menyelamatkan kyai- kyai yang baru ditangkapi Belanda. Saya sendiri belum bisa memastikan, ini kan urusannya ahli sejarah. Terus pada tahun 1927 Bung Karno mendirikan PNI. Tahun 1928 ada Kongres pemuda, yang menurut saya, ini pantas disebut sebagai hari kelahiran bangsa Indonesia. Tahun 1931 PNI-nya Bung Karno dibubarkan, kemudian dibentuk Partindo (Partai Indonesia Raya) yang dipimpin oleh Sartono. Sebagian anggota PNI yang tidak setuju dengan pembentukan Partindo, kemudian meneruskan nama PNI tetapi dengan singkatan lain, Pendidikan Nasional Indonesia atau yang disebut dengan PNI Baru. Tahun 1936 Boedi Oetomo bergabung dengan Persatuan Bangsa Indonesia (PRI). Dan seterusnya....” (Wawancara, tanggal 4 Juni 2019).

Lebih lanjut KH. Wildan menjelaskan, bahwa sejak kelahirannya, NU selalu ditarik-tarik ke dalam siklus politik praktis, sehingga meskipun bukan organisasi politik, NU termasuk bagian dari makhluk politik yang tidak bisa lepas dari politik.

Jika Gus Wildan melihat keterlibatan NU dalam politik disebabkan NU mempunyai massa besar, tidak demikian dengan Gus Abdullah Jalal, yang mengartikan bahwa NU menjadikan politik hanya sebagai instrumen untuk mencapai tujuan NU. Sebagaimana pendidikan, dakwah, ekonomi, dan lainnya, politik juga merupakan sarana mengejawantahkan visi dan misi organisasi. Politik dalam konteks NU bukan upaya mendapatkan kekuasaan atau hanya demi kepentingan yang oportunis. Mengenai hal ini, Gus Jalal menjelaskan lebih lanjut sebagai berikut:

"NU tidak main politik praktis, namun kalau NU memperjuangkan agama ini menggunakan instrumen politik, ini tidak salah? Artinya NU harus tidak anti politik. Apakah politik kebangsaan, kerakyatan atau juga politik kekuasaan, asalkan kekuasaan yang ada dapat dijadikan instrumen bukan tujuan.” (Wawancara, tanggal 7 Juni 2019).

Dari beberapa pandangan di atas, penulis dapat menyimpulkan bahwa pertama, NU tetap tidak bisa lepas dari politik, akan tetapi politik dalam perspektif NU adalah politik kebangsaan dan partisipatoris. Kcdua, dengan massa yang besar NU tidak mudah memisahkannya dengan politik, termasuk politik praktis. Ketiga, NU menjadikan politik sebagai instrumen dalam mencapai tujuantujuan organisasinyanya. Di sinilah para kyai sebenarnya sering melakukan tindakan-tindakan akrobatik, berlawanan dengan keputusan struktural organisasi.

Akan tetapi menurut penulis, seperti yang dikatakan Gus Jalal, bahwa yang harus menjadi perhatian utama dari politik kyai adalah pertama, disadari atau tidak, kyai-kyai NU telah sangat dalam terlibat dalam upaya dukung-mendukung capres, Pilgub, Pilbub. Memang, keterlibatan kyai dalam momen-momen politik bukanlah hal baru. Sejak masa-masa awal kemerdekaan komunitas kyai 
senantiasa terlibat dalam berbagai peristiwa politik. Namun, keterlibatan tersebut tidak bersifat monopolitik. Namun, hal yang paling mengerikan adalah kalau terjadi "perselingkuhan" antara pemegang kekuasaan dengan kyai.

Kedua, komunitas kyai sebagai modal sosial NU yang tidak dimiliki komunitas lain, seharusnya ditempatkan (atau menempatkan diri) sebagai subyek, bukan sebagai obyek. Mereka dibutuhkan hanya pada saat-saat politisi membutuhkan dukungan. Setelah itu, kyai kembali dipandang sebagai komunitas tradisional tiada guna.

Ketiga, kyai NU harus sadar betul bahwa apa pun sikap politik mereka akan membawa dampak terhadap masyarakat NU yang masih memandang kyai sebagai panutan, bukan hanya dalam urusan keagamaan tapi juga dalam hal sikap politik. Oleh karena itu, kearifan kyai NU dalam membentuk sikap politik warganya juga harus diikuti oleh kesadaran akan dampak sikap tersebut.

\section{PENUTUP}

Manusia tidak akan pernah lepas dari kehidupan politik karena manusia adalah makhluk politik (zoon politicon). sejak kelahirannya, NU selalu ditarik-tarik ke dalam siklus politik praktis, sehingga meskipun bukan organisasi politik, NU termasuk bagian dari makhluk politik yang tidak bisa lepas dari politik. Hubungan NU dan politik sesungguhnya bagai pinang dibelah dua, keduanya tidak dapat dipisahkan. Mayoritas kyai menyatakan bahwa NU dan politik adalah dua entitas yang tidak bersifat diametral, keduanya berhubungan satu sama lain. Hanya saja, politik NU haruslah politik kebangsaan bukan politik praktis yang sibuk memperebutkan kekuasaan. NU sebagai jam'iyah ijtima'iyyah diniyyah harus menjadi rabmatan lil alamin, sekaligus kontrol bagi kehidupan politik

Hubungannya dengan NU bukan politik kekuasaan melainkan politik partisipatoris, yaitu politik di mana NU juga berperan aktif dalam membangun bangsa dan negara (civil Society), Jika NU ada hubungannya dengan pemerintah maka itu hanya sebatas kewajiban sebagai rakyat, NU berpolitik hanya sebagai instrumen untuk mencapai tujuan NU. Sebagaimana pendidikan, dakwah, ekonomi, dan lainnya, politik juga merupakan sarana mengejawantahkan visi dan misi organisasi. Politik dalam konteks NU bukan upaya mendapatkan kekuasaan atau hanya demi kepentingan yang oportunis.

\section{DAFTAR PUSTAKA}

Abdullah, M. Amin., 2015. Agama, Kebenaran, dan Relativitas (Sebuah Pengantar). Dalam Gregory Baum Agama dalam Bayang-bayang Relativisme Sebuah Analisis Sosiologi Pengetabuan Karl Mannheim tentang Sintesa Kebenaran Historis-Normatif. Yogyakarta: PT. Tiara Wacana Bekerjasama dengan Siprus.

Archer, M.S, 1982a, 'Morphogenesis versus Structure and Action; British Journal of Sociology, Vol. 33 No.4 ,1982b, 'Human Agency and Social Structure: A Critique of Giddens ; dalam Anthony Giddens: Consensus and Controversy, Ed. Clark, )., Modgil, C., dan Modgil, J., Brighton: Falmer Press

Avesson, M. and Skoldberg, K., 2010, Reflexive Methodology: New Vistas for Qualitative Research, London: Sage Publications. 
Barnes, 2011, "Symbolic Interaction at the End of the Century", dalam Ritzer, G. and Smart, B., Handbook of Social Theory, London: Sage Publications.

Beilharz, P., 2012, Sosial Theory: A Guide to Central Thinkers, Alih Bahasa Sigit Jatmiko, Yogyakarta: Pustaka Pelajar.

Berger, P. And Luckmann., 1967, The Social Construction of Reality, Garden City, N.Y.: Doubleday.

Bryant, C.G.A., and David, 1991, Giddens' Theory of Structuration: A Critical Appreciation. London: Routledge.

Craib, I., 1992, Anthony Giddens, London: Routledge.

Creswell, J.W., 1994, Research Design: Qualitative and Quantitative Approaches, Jakarta: KIK Press Kalangan Sendiri

Denzin, N.K., dan Lincoln., 2000, Handbook of Qualitative Research. London: Sage Publications.

Dessler, G., 1992, Organization Theory: Integrating Structure and Behavior. Singapore: Simon and Schuster (Asia) Pte. Ltd.

Giddens, A., 1977, Studies in Social and Political Theory. London: Hutchinson , 1979, Central Problems in Social Theory. London: Mac Milan 2014, The Constitution of Society The Outline of The Theory of Structuration. Cambrigde: Polity Press 2009, "A Reply to My Critics" dalam Social Theory of Modern Societies: Anthony Giddens and his Critics, Ed. Held dan Thompson, Cambridge: Cambridge University Press. 2011, Modernity and Self-Identity. Cambrigde: Polity Press 2012, Thr Third Way The Renewali of social democracy. Cambrigde: Polity Press, 2016, Sociology Fourth Edition. Oxford: Blackwell Publishing Ltd.

Greetz, C., 1961. The Religion of Java. Glencoe: The Free Press. , 1959a. "The Javanese Kyai: The Changing Role of Cultural Broker", dalam Comparative Studies in Society and History, (2):250-256

1959b. "The Javanese Village", dalam G William Skinner, (ed.). Local Ethnic and National Loyalities in Village Indonesia: A Symposium. Yale University Cultural Report Series, Southeast Asian Studies.

1973. "Religion as a Cultural System", dalam The Interpretation of Culture. New York: Basic Book.

Guba, E., 1990, "The Alternative Paradigm", dalam Guba, E., Ed., The Paradigm Dialog, Newbury Park, CA: Sage Publications.

Haralambos, M. Holborn, M., dan Heald, 2000, Sociology: Themes and Perspectives, Hammersmith: HarperCollins Publisher Ltd.

Hefner, Robert W. 1987. "Islamizing Java?: Religion and Politics in Rural East Java", dalam The Journal of Asian Studies, 46 (3): 533-553.

Hertz, R., Ed., 1996, "Introduction: Reflexity and Voice", Qualitative Sociology, 19: 3-9.

Holton, R., 2011, "Symbolic Interaction at the End of the Century", dalam Ritzer, G. and Smart, B., Handbook of Social Theory, London: Sage publications

Horikoshi, Hiroko, 1976, " A Traditional Leader in a Time of Change: The Kyai and Ulama in West Java". Disertasi Doktor, University of Illinois,

Ismail SM. 2012. Dinamika Pesantren dan Madrasah. Yogyakarta: Pustaka Pelajar.

Mansurnoor, 2017, Islam in an Indonesian World, Ulam of Masura, Yogyakarta: Gajah Mada University Press.

Maxweel, Joseph A. 1996. Qualitative Research Design an Interactive Approach. California: Sage Publication.

Neuman. W.L., 1997, Sosial Research Method: Qualitative and Quantitatif Approaches. Boston: Allyn and Bacon.

Newman, I., dan Benz, C. R., 1998, Qualitatif-Quantitative Research Methodology: Exploring the Interactive Continum, Carbondale: Souther Illinois University Press.

Rifa'i, Ahmad. 2015. Islam sebagai Kambing Hitam. Dalam Media Indonesia tanggal 02-04. Sila e-mel KV dividya@,tm.net.my

Ritzer, George, 2010, Sociological Theory, Singapore: McGraw-Hill Book. Companies House, Inc. 
Robertson, Roland, 1970, The Sociological Interpretation of Religion, New York: Schocken Books. Schroeder, Ralph, 1992, Max Weber and the Sociology of Culture, London: Sage Publication Schlegel, Stuart S. 1977. Grounded Research di dalam Ilmu-ilmu Sosial. Aceh: PLPIIS.

Sparringa, Daniel, 1997, Discaourse, Democracy an Intellectuals in New Order Indonesia: A Qualitative Sociological Study, Australia: A Thesis Submitted for the Degree of Doctor of Philosophy of The Flinders University of South Australia.

, 2002, "Analisis Wacana: Sebuah Pendekatan untuk Kajian Sosial Budaya, Prasasti, Jurnal Ilmu dan Seni Fakultas Bahasa dan Seni Universitas Negeri Surabaya, No. 45/ Tahun Xii/Mei 2002.

Suprayogo, Imam, 2007, Kyai dan Politik: Membaca Citra Politik Kyai, Malang: UIN Malang Press.

Thompson, John B., 1984, Ideology and the Analysis of Discourse: A Critical Introduction to the Work of Michel Pecheux" dalam Studies in The Theori of Ideology. University of California Press, USA.

Turmudi, Endang, 2004, Perselingkuhan Kiai dan Kekuasaan, Yogyakarta,: LkiS.

Turner, Bryan S, 1998, The Blackwell Companion to Social Theory, Blackwell Publisher, USA

Tischler., Henri L., 1990, Introduction to Sociology, Chicago: Holt, Rinehart and Winston. 